See discussions, stats, and author profiles for this publication at: https://www.researchgate.net/publication/343057832

\title{
Motif Misi \& Pertumbuhan Gereja Masa Kini
}

Preprint · September 2018

DOI: 10.13140/RG.2.2.34081.63849

CITATIONS

0

4 authors, including:

Fransiskus Irwan Widjaja

1. Real Theological School, Batam (STT Real) Indonesia

14 PUBLICATIONS 4 CITATIONS

SEE PROFILE

Some of the authors of this publication are also working on these related projects:

Article View project

Conference View project 


\title{
Motif Misi \& Pertumbuhan Gereja Masa Kini
}

\author{
Fransiskus Irwan Widjaja ${ }^{1}$, Selvyen Sophia, ${ }^{2}$ Otieli Harefa, ${ }^{3}$ Rini Sumanti Sapalakkai \\ Prodi Teologi, STT Real Batam \\ Prodi Teologi, STT Real Batam \\ Prodi Teologi, STT Real Batam \\ Prodi PAK, STT Real Batam \\ irwanwidjaja.fiw@gmail.com
}

\begin{abstract}
The growth of the Church in Indonesia in particular and the world in general see a large number of mega church growths in the number of souls and buildings as places of worship. When the research was released by the Academic Research Institute, church growth did not have a significant impact. The author dug up data from various sources and found it to be a mission in the early centuries of the spread also had various motives. In this paper, the author raises a variety of motives found and also various kinds of church growth that are summarized.
\end{abstract} Keywords: mission motives, church growth

\begin{abstract}
Abstrak
Pertumbuhan Gereja di Indonesia secara khusus dan dunia secara umum melihatkan banyaknya pertumbuhan gereja mega dalam jumlah jiwa dan Gedung sebagai tempat ibadah. Ketika penelitian yang di keluarkan Lembaga Research akademik, pertumbuhan gereja ternyata tidak membawa dampak yang signikan. Penulis menggali data dari berbagai sumber dan mendapatkan ternyata bermisi di abad abad awal penyebaran juga mempunyai berbagai motif. Dalam tulisan ini, penulis mengangkat berbagai macam motif yang di temukan dan juga berbagai macam pertumbuhan gereja yang di rangkum.

Keywords: motif misi, pertumbuhan gereja
\end{abstract}

\section{PENDAHULUAN}

Tuhan adalah Tuhan yang memiliki misi. DIA adalah seorang misionaris dari surga. I Timotius 2: 4, "yang ingin semua orang diselamatkan dan mendapatkan pengetahuan tentang kebenaran." Misi adalah mencari dunia yang hilang dan membawanya ke dalam kasih dan penyelamatan Tuhan melalui Yesus Kristus dan membuat bertanggung jawab dan berperan aktif melipat gandakan orang percaya di dalam tubuh Kristus ${ }^{1}$. Pesan terakhir yang Yesus lakukan sebelum Ia naik ke surga adalah memberi murid-murid-Nya Amanat Agung: Karena itu pergilah, jadikanlah semua bangsa murid-Ku dan baptislah mereka dalam nama Bapa dan Anak dan Roh Kudus, (Matius 28:19). Dalam Markus 16:15: Dan Dia berkata kepada mereka, "Pergilah ke seluruh dunia, beritakanlah Injil kepada segala makhluk

\footnotetext{
${ }^{1}$ Fransiskus Irwan Widjaja, Misiologi Antara Teori, Fakta Dan Pengalaman, 1st ed. (Yogyakarta: Andi Offset, 2018) hal 8.
} 
Lukas 24:47: dan lagi: dalam nama-Nya berita tentang pertobatan dan pengampunan dosa harus disampaikan kepada segala bangsa, mulai dari Yerusalem.

Sedangkan dalam Yohanes 20:21, Yesus berbicara tentang penginjilan dunia ketika Dia berkata, "Sama seperti Bapa mengutus Aku, demikian juga sekarang Aku mengutus kamu." Dan sebelum Dia naik ke surga, Kisah Para Rasul 1: 8, "Kamu akan menerima kuasa ketika Roh Kudus turun ke atasmu, dan kamu akan menjadi saksi-Ku di Yerusalem dan semua Yudea dan Samaria, dan sampai ke ujung bumi."

Misi ini berasal dari hati Allah melalui penginjilan dan pemuridan, adalah untuk memimpin orang lain kepada Allah, menjadi murid yang menyaksikan, misi pencarian (membawa dunia yang hilang), misi keselamatan (melalui Yesus Kristus) dan misi pemeliharaan - memberi makan (membuat tubuh Kristus menjadi bertanggung jawab). Secara holistik Irwan menegaskan Misi memegang peran yang sangat penting untuk meningkatkan dan mengembangkan kualitas sumber daya manusia. ${ }^{2}$

Dewasa ini, menurut pengamatan penulis selaku praktisi misi dalam gereja, gereja hanya melakukan tugas-tugas yang dianggap bagian dari program gereja, tidak seperti pelayanan gerejawi lainnya. Tujuan Amanat Agung adalah esensi dan fondasi gereja. Gereja ada karena pelayanan misi, dan karena itu, gereja harus menjadi gereja yang misionair. Secara umum, gereja lebih berkonsentrasi pada sumber daya gereja pada bangunan dan peralatan (sarana pendanaan infrastruktur) untuk memuaskan (menghibur) jemaat mereka dalam pujian dan penyembahan (Pujian \& penyembahan) daripada menyenangkan Tuhan dengan misi dan jangkauan jiwa. Untuk itu kita perlu melihat motif motif dalam bermisi yang di kumpulkan penulis dari berbagai sumber serta pertumbuhan gereja yang terjadi saat ini.

\section{METODE}

Penelitian ini menggunakan metode deskriptif kualitatif dengan pendekatan library research dengan mempelajari misi-misi yang ada dan dijabarkan dalam diskusi untuk membandingkan motif yang sesbenarnya dan hasil dari model pertumbuhan gereja yang ada.

\section{HASIL DAN PEMBAHASAN}

Penulis menyimpulkan bahwa misi pada umumnya berada di dalam masa pengujian, karena dari sumber penelitian yang di keluarkan Gordon Cornwell University, selama kurun waktu 50 tahun $1970-2020^{3}$ pertumbuhan umat Kristiani hanya bertambah $0,1 \%$, sementara di sisi lain penulis melihat bahwa ada banyak gereja "mega" dengan jemaat yang cukup besar. Itu berarti ada sesuatu yang perlu di kaji ulang dan

\footnotetext{
${ }^{2}$ Fransiskus Irwan Widjaja, "Mission Strategy Through Education," in Kingdom Economy And Mission, 2018, 77-84.

${ }^{3}$ Centre for the study of Global Christianity, Christianity in Global Context, 1970-2020, n.d.
} 
memperhatikan orang terlibat dalam misi juga perlu diperiksa. Verkuyl ${ }^{4}$ membedakan motif misi menjadi dua jenis: motif yang murni dan motif yang tidak murni.

\section{Motif-motif yang murni:}

a. Motif ketaatan

Motif ketaatan memainkan peranan yang sangat penting di dalam keseluruhan tulisan-tulisan para rasul. Paulus berbicara tentang keharusan memberitakan Injil (1 Kor 9:16) dan sebagai orang yang berhutang kepada semua orang (Rom 1:14). Motif ini telah menginspirasikan tak terhitung orang yang mengabdikan seluruh hidupnya bagi pelayanan misi. Ketika William Carey menyadari bahwa pendapat yang mengatakan tanggung jawab misi hanya berlaku pada zaman para rasul adalah pandangan yang salah sama sekali, dia menulis "An Inquiry into the Obligation of Christians to Use Means for the Conversion of the Heathen. Dalam tulisannya itu dia menjelaskan dasar alkitabiah tentang kewajiban orang Kristen untuk mempertobatkan orang kafir.

b. Motif Kasih, Kemurahan hati dan Belas kasih

Alkitab cukup kuat menekankan motif kasih, Kemurahan hati dan belas kasih di dalam pekerjaan misi. Yunus, yang diselamatkan oleh karena kasih dan kemurahan Allah kepadanya telah dtuduh tidak memiliki hal ini. Paulus menggambarkan orang yang tidak hidup dalam terang janji Allah sebagai terasing dari Alah yang hidup dan hidup tanpa pengharapan di dunia (Ef 2:1-10). Kita juga dapat melihat dalam 1 Tes 2:8 Kasih yang mendalam ketika dia berkata "Demikianlah kami, dalam kasih sayang yang besar akan kamu, bukan saja rela membagi Injil Allah dengan kamu, tetapi juga hidup kami sendiri dengan kamu, karena kamu telah kami kasihi." Tetapi orang yang tidak merasakan pangilan untuk memberitakan Injil di lingkungan mereka sendiri maupun di tempat yang jauh adalah pertanda kurangnya kasih dan kemurahan hati di dalam mereka dan menghalangi kasih Allah mengalir atas orang-orang yang belum percaya. Tekanan penting dari "misi atau misi Tuhan" berbicara tentang Tuhan sebagai pengirim di mana Tuhan adalah sumber, penggagas, aktor dinamis, pelaksana, dan pemenuhan misi-Nya. ${ }^{5}$

\section{c. Motif Memuliakan Allah}

Memuliakan Allah adalah motif misi terdapat di seantero Perjanjian Baru. Paulus mengatakan kerinduannya "... supaya firman Tuhan beroleh kemajuan dan dimuliakan” dan agar "...segala lidah mengaku: "Yesus Kristus adalah Tuhan," bagi kemuliaan Allah, Bapa" (2 Tes 3:1; Flp 2:11). Di dalam Roma 11:33, 36, Paulus juga berbicara tentang "Bagi Dialah kemuliaan sampai selama-lamanya". Motif memuliakan Allah ini juga telah menginspirasikan banyak misionaris yang selama berabad-abad terlibat dalam pekerjaan misi.

\footnotetext{
${ }^{4}$ A. Şerban, "Translation and Genre: Sacred Texts," Encyclopedia of Language \& Linguistics (2006): 47-
} 53.

\footnotetext{
${ }^{5}$ Fredy Simanjuntak, “Mission Driven Prayer,” May 15, 2020, https://doi.org/10.31219/osf.io/znef2.
} 


\section{d. Motif Eskatologis}

Motif kerajaan memainkan peranan penting di dalam kitab-kitab Injil. Dalam doa Bapa kami, Yesus mengajarakan "Datanglah kerajaanMu" mengungkapkan motif ini dengan singkat.

e. Motif kemendesakan

Motif kemendesakan sangat erat dengan motif pengharapan kedatangan kerajaan. Para rasul sering memperingatkan jemaat untuk melakukan yang baik selagi masih ada waktu (Ef 5:16-17; Kol 4:5; Gal 6:10).

f. Motif Pribadi

Dalam 1 Kor 9:23 Paulus berkata "segala sesuatu ini aku lakukan karena Injil, supaya aku mendapat bagian dalamnya." Ketika Paulus menungkapkan motif misi ini, dia menunjuk kepada fakta dalam pengalaman manusia, yaitu bahwa siapa yang mendorong orang lain untuk percaya juga memperkuat imannya sendiri. Orang yang memberitakan Injil kepada yang lain akan mendapati bagi dirinya sendiri bahwa ini adalah "menjadi mata air di dalam dirinya, yang terus-menerus memancar sampai kepada hidup yang kekal." (Yoh 4:14). Tetapi gereja dan orang Kristen yang tidak lagi didorong oleh motif ini bagi misi akan menjadi gereja atau orang yang berpusat pada dirinya sendiri dan suka berdebat/berbantah-bantahan.

\section{Motif yang tidak murni}

\section{a. Motif Imperialism}

Selama abad 15 dan 16, Paus Nicholas V dan Alexander VI memerintahkan Spanyol dan Kemudian Portugis untuk melebarkan kekuasaan politis mereka di Asia, Afrika dan belakangan juga di Amerika tapi juga dengan keuletan untuk mengembangkan kekuasaan Gereja KAtolik Roma. Dengan cara ini, Paus mengaitkan misi dengan otoritas politik dimana misi menjadi alat juga untuk mengokohkan kekuasaan politis Spanyol dan Portugal. Sekalipun demikian, kita harus menyadari bahwa tetap ada misionaris yang melayani dengan motif murni seperti: Fransiscus Xaverius

b. Motif budaya

Selama abad ke 19, motif budaya sering menggantikan motif yang alkitabiah untuk misi. Pekerjaan misi dilakukan bersama-sama dengan mentransfer kebudayaan missionaries di lading misi. Pada dasarnya, motif ini beangkat dari anggapan bahwa budayanya sendiri lebih tinggi dari kebudayaan lain. Pekerjaan misi dilakasanakan karena kasihan melihat kehidupan masyarakat dari budaya lain yang dianggap lebih rendah dan karena itu perlu ditolong. Seorang tokoh teologi bernama Schleirmacher yakin bahwa pekerjaan misi seharusnyalah dilakukan dengan mentransfer budaya. Sedangkan ahli lain, Ernst Troeltsch berpendapat bahwa ada berbagai agama yang muncul dan berkembang di dalam sejarah, tetapi agama Kristen adalah agama yang memiliki posisi lebih tinggi dari dari semua agama itu. Karena itu Troeltsch menghimbau untuk menempatkan kembali mandate Kristen 
untuk misi dengan pemahaman yang saling menguntungkan dan melakukan perubahan dalam kebudayaan dan agama masyarakat lain.

\section{c. Motif komersial}

Motif ini tujuannya hanya mencari keuntungan finansial sebanyak-banyaknya. Motif ini juga sudah pernah diperingatkan oleh rasul Paulus dalam Filipi 1:15-17 "Ada orang yang memberitakan Kristus karena dengki dan perselisihan, tetapi ada pula yang memberitakan-Nya dengan maksud baik. Mereka ini memberitakan Kristus karena kasih, sebab mereka tahu, bahwa aku ada di sini untuk membela Injil, tetapi yang lain karena kepentingan sendiri dan dengan maksud yang tidak ikhlas, sangkanya dengan demikian mereka memperberat bebanku dalam penjara.

\section{d. Motif Kolonialisme Ekklesiastikal}

Motif ini adalah merupakan penjajahan rohani yang dilakukan oleh suatu denominasi gereja tertentu. Penjajahan ditujukan kepada gereja-gereja kecil yang tidak berdaya (dibidang pendanaan) sehingga terpaksa harus tunduk dan takluk pada gereja local lainnya yang lebih kuat pendanaannya. Masalah ini juga bisa timbal dalam hubungan antara apa yang disebut dengan "mother church" (Gereja Induk) dengan gereja-gereja yang didirikan oleh gereja induk, dimana gereja induk memaksakan kebijakannya kepada gerejagereja yang didirikannya. Masalah sering muncul dalam hubungan antara gereja-gereja di Jerman dan Belanda dengan gereja buah misi di Indonesia.

Dengan motif seperti apa yang di katakan Verkuil, kita perlu juga membandingkan atau mengamati pertumbuhan gereja yang terjadi. Penulis menemukan beberpa definisi pertumbuhan gereja yang mungkin bisa di pakai untuk penelitian lanjutan.

\section{Pertumbuhan Gereja}

Pertumbuhan dalam gereja di definisikan secara umum menyangkut dua bagian; pertumbuhan kualitatif adalah pertumbuhan ke dalam, dimana setelah seseorang dimenangkan, tidak cukup hanya menjadi jemaat. Melalui pemuridan dan pelatihan, kehidupan rohaninya meningkat. Ia tidak lagi hanya sebagai jemaat biasa tetapi telah meningkat menjadi aktivis (pekerja magang sebelum ditahbiskan) dan terus belajar sampai pertumbuhan tingkat rohaninya mencapai level pekerja dan mulai melayani dan juga mulai menjangkau jiwa.

Pertumbuhan kuantitatif adalah pertumbuhan jemaat yang meningkat melalui program-program penjangkauan. Dalam hal tersebut, jumlah jemaat bertambah dan mulai meningkat secara kuantitatif. Pertumbuhan juga bisa melalui kelahiran, perpindahan dari jemaat lain, dan bangkitnya jemaat lama yang tidak aktif dan mulai ke gereja lagi.

Setiap pertumbuhan mempunyai tujuan. McGavran $^{6}$ mencetuskan dengan baik. Menurut McGavran, dalam rangka memenuhi panggilan misioner mereka, gereja harus

\footnotetext{
${ }^{6}$ Donald McGavaran, Understanding Church Growth (Grand Rapids: Eerdmans Publishing, 1990).133
} 
mengunakan seluruh kemampuannya untuk menghasilkan angka pertumbuhan gereja. Perluasan kuantitatif adalah prioritas tertinggi dalam urusan gereja.

Gereja perlu mempertimbangkan secara serius pola-pola sosial budaya masyarakat setempat ketika mulai melayani di masyarakat tertentu supaya dapat mengakarkan gereja lebih kuat di tanah sosial/budaya masyarakat tersebut. Seorang misionaris yang mulai bekerja di masyarakat tertentu harus memilih keluarga-keluarga kunci yang memegang peran kepemimpinan. Karena semua keluarga di dalam masyarakat homogen saling berhubungan/terikat satu dengan yang lain, maka jika berhasil mempertobatkan keluarga kunci maka hal ini akan menghasilkan efek bola salju sehingga pada akhirnya semua keluarga besar akan merespon Injil.

Peter Wagner, berdasarkan buku karangan Donald McGavran (The Bridges of God dan How Churches Grow) menyatakan pertumbuhan Gereja, berbicara tentang "semua yang terlibat dalam membawa pria dan wanita yang tidak memiliki hubungan pribadi dengan Yesus Kristus ke dalam persekutuan dengan Dia dan menjadi anggota gereja yang bertanggung jawab."

Kraus C. Norman 7 menemukan "pertumbuhan" dalam Perjanjian Baru paling sering digunakan untuk menunjukkan perkembangan menuju kedewasaan di dalam tubuh Kristus (Ef. 4: 13-16). Tapi bisa juga diterapkan pada peningkatan jumlah murid dan pelipatgandaan gereja (Kis. 2: 47). Kedua pertumbuhan ini penting untuk pelaksanaan misi yang efektif yang telah diberikan kepada gereja. Pertumbuhan tersebut mencakup kemenangan, pemeliharaan, peningkatan dan termasuk pertumbuhan jumlah jemaat dan pelipatgandaan gereja.

Banyak ahli memberi banyak penjelasan tentang pertumbuhan gereja, namun penulis percaya bahwa ada faktor umum yang terkait dengan pertumbuhan Gereja; Pertumbuhan adalah bagian dari sifat gereja. Penting dan perlu untuk mengamati berbagai jenis pertumbuhan Gereja. Pertumbuhan gereja dapat dilakukan dengan banyak cara atau seperti berikut ini:

1. Pertumbuhan Internal (Internal Growth): disebut juga sebagai Pertumbuhan Biologis. Ini berarti bahwa gereja tumbuh dalam dirinya sendiri. Menurut Wagner dalam bukunya Strategi untuk Pertumbuhan Gereja, "anak-anak keluarga Kristen tumbuh melalui program spesifik yang dirancang oleh Gereja dan anak-anak muda membawa orang muda lainnya kepada Kristus dan masuk ke dalam keanggotaan Gereja. ${ }^{8}$

2. Pertumbuhan Numerik (Numeric Growth): bagian dari pertumbuhan biologis. Hal ini terjadi ketika seorang anak lahir dalam keluarga orang percaya dan dengan demikian secara otomatis menjadi anggota gereja tempat orang tua berada. ${ }^{9}$

\footnotetext{
${ }^{7}$ Kraus C. Norman, Introduction: Mission and Church Growth" in Mission, Evangelism and Growth (Pensylvania: Herald Press, 1980).30-31

${ }^{8}$ Peter C. Wagner, Strategy for Church Growth (California: Regal Book, 1987).115

${ }^{9}$ Roy Pointer, How Do Churches Grow (Basingstoke: Mashal Morgan \& Scott, 1984). 105
} 
3. Pertumbuhan transfer/perpindahan (Transfer growth). Ini terjadi ketika seorang percaya berpindah dari satu gereja ke gereja lainnya karena berbagai alasan, misalnya perubahan tempat tinggal, perubahan tempat kerja, dan lain-lain. ${ }^{10}$

4. Pertumbuhan Konversi (Conversion Growth): Hal ini terkait dengan membagikan Injil kepada mereka yang tidak percaya kepada Yesus Kristus sebagai Tuhan dan Juruselamat. Ketika mereka membuat komitmen kepada Kristus, mereka dibawa ke Gereja dan dibimbing untuk pertumbuhan. ${ }^{11}$

5. Pertumbuhan Restorasi (Restoration Grwoth). Inilah jenis pertumbuhan yang terjadi ketika orang-orang Kristen yang pernah meninggalkan Tuhan (murtad) kembali kepada Tuhan dan bergabung kembali dengan gereja tersebut. ${ }^{12}$

6. Pertumbuhan Bridging (penjembatanan). Ini berarti membangun atau menanam gereja baru dalam budaya yang berbeda dengan gereja induk (pengutus). ${ }^{13}$

Dalam semua jenis pertumbuhan, ada faktor umum yang dilakukan dalam pertumbuhan yaitu penginjilan. Model-model program penginjilan mempunyai andil dalam memenangkan jiwa jiwa tersebut. Dengan demikian, perlu diperhatikan bahwa penginjilan sangat penting dalam keseluruhan proses pertumbuhan gereja.

\section{KESIMPULAN}

Menyikapi perkembangan dan pertumbuhan gereja, hendaknya gereja tetap melakukan amanat Agung, penginjilan dan penjangkauan adalah bagian yang tidak terlepas dari gereja. Gereja ada bagian dari misi dan misi ada karena gereja. Di dalam misi selalu ada penginjilan dan penjangkauan. Apapun motif yang membuat gereja bermisi di kembaliakan ke esensi kenapa gereja eksis. Penulis menyarankan, bahwa gereja harus tetap melakukan bagiannya, apapun kondisi nya.

\section{KEPUSTAKAAN}

Centre for the study of Global Christianity. Christianity in Global Context, 1970-2020, n.d. Green, Michael. Evangelism Now and Then. Illionois: InterVarsity Press, 1997.

McGavaran, Donald. Understanding Church Growth. Grand Rapids: Eerdmans Publishing, 1990.

Norman, Kraus C. Introduction: Mission and Church Growth" in Mission, Evangelism and Growth. Pensylvania: Herald Press, 1980.

Pointer, Roy. How Do Churches Grow. Basingstoke: Mashal Morgan \& Scott, 1984.

Şerban, A. "Translation and Genre: Sacred Texts." Encyclopedia of Language \& Linguistics (2006): 47-53.

Simanjuntak, Fredy. "Mission Driven Prayer," May 15, 2020.

https://doi.org/10.31219/osf.io/znef2.

Wagner, Peter C. Strategy for Church Growth. California: Regal Book, 1987.

${ }^{10}$ Ibid.

${ }^{11}$ Ibid.

${ }^{12}$ Ibid.106

${ }^{13}$ Michael Green, Evangelism Now and Then (Illionois: InterVarsity Press, 1997).13-14 
Widjaja, Fransiskus Irwan. Misiologi Antara Teori, Fakta Dan Pengalaman. 1st ed. Batam: Andi Offset Yogyakarta, 2018.

. "Mission Strategy Through Education." In Kingdom Economy And Mission, 7784, 2018. 